\title{
Tarımsal Ürünlerde Rekabet Gücü: Bölgesel Bir Analiz*
}

\section{Competitiveness of Agricultural Products: A Regional Analysis}

\section{Halil TUNCA ${ }^{1}$}

${ }^{1}$ Pamukkale Üniversitesi İktisadi ve İdari Bilimler Fakültesi htunca@pau.edu.tr Orcid ID: 0000-0002-1449-940X

$\begin{array}{ll}\text { Makale Bilgisi: } & \text { Araştırma Makalesi } \\ \text { Geliş Tarihi: } & 22.03 .2020 \\ \text { DüzeltmeTarihi: } & 10.05 .2020 \\ \text { Kabul Tarihi: } & 05.06 .2020\end{array}$

\section{Özet}

Tarım sektörü, gıda güvenliğini sağlama ve istikrarlı bir ekonomik gelişmeye yardımcı olmak gibi hayati görevlere sahiptir. Bu görevlerin başarılı bir şekilde gerçekleştirilebilmesi için hangi tarımsal ürünlerde karşılaştırmalı üstünlüğe sahip olunduğunun bilinmesi gerekmektedir. Bu sebepten ötürü bu çalışmanın amacı Türkiye'deki illerin tarımsal ürün gruplarındaki karşılaştırmalı üstünlü̆̆̈̈nün hesaplanmasıdır. Bunun için Balassa tarafindan geliştirilen Açıklanmış Karşılaştırmalı Üstünlükler indeksi kullanılmıştır. 2015 ve 2018 yılları için yapılan hesaplamada Uyumlaştırılmış Mal Tanım ve Kod (HS) sistemi kullanılmış ve ihtiyaç duyulan veriler TÜIIK'dan elde edilmiştir. Çalışma sonuçları herhangi bir ilin sahip olduğu tarmsal performans ve rekabetçi yapı açısından ön plana çıkmadığını göstermektedir. HS 04 ve HS 11 ürün gruplarında karşılaştırmalı üstünlüğe sahip olan il sayısı en fazladır. HS 13 ve HS 24 ise en kötü performansa sahip olan ürün gruplarıdır. Ankara, Adana, Burdur, Bursa, Denizli, Gaziantep, Mersin ve Konya karşılaştırmalı üstünlüğe sahip olan illerdir. Ardahan, Bayburt, Karaman, Muş, Kütahya, Kars, Elazı̆̆, Erzurum, Adryaman ve Bitlis gibi illerin ise hiçbir ürün grubunda karşılaştırmalı üstünlüğe sahip olmadıkları görülmüştür.

Anahtar Kelimeler: Tarım, Açıklanmış Karşılaştırmalı Üstünlükler, Türkiye, Il

JEL kodları: F10, F14, Q17, R19

$\begin{array}{ll}\text { Article Info: } & \text { Research Article } \\ \text { Date Submitted: } & 22.03 .2020 \\ \text { Date Revised: } & 10.05 .2020 \\ \text { Date Accepted: } & 05.06 .2020\end{array}$

\section{Abstract}

The agricultural sector has vital tasks such as providing food security and helping sustainable economic development. In order to fulfill these tasks, it is required to know which agricultural products have comparative advantages. For these reason, the aim of this study is to measure the comparative advantages in agricultural product groups of provinces in Turkey. Hence it was employed Revealed Comparative Advantages index developed by Balassa. This study cover 2015 and 2018, and Harmonized Goods Definition and Code (HS) system was used and all required data were obtained from TURKSTAT. The results of this study show that any province hasn't a plain comparative advantage in any agricultural product group. In the HS 04 and HS 11 product groups, the number of provinces that have a comparative advantage is the highest. HS 13 and HS 24 are the worst performing product groups. Ankara, Adana, Burdur, Bursa, Denizli, Gaziantep, Mersin and Konya are provinces that the highest agricultural comparative advantages. On the other hand, it is observed that provinces such as Ardahan, Bayburt, Karaman, Muş, Kütahya, Kars, Elazı̆̆, Erzurum, Adıyaman and Bitlis do not have comparative advantages in any agricultural product groups.

Keywords: Agriculture, Released Comparative Advantages, Turkey, provinces

JEL codes: F10, F14, Q17, R19

\footnotetext{
* Çalışma etik kurul ve yasal izin alınması kapsamında değildir. İntihal raporu alınmıştır.
} 


\section{GIRISS}

Artan nüfusun beslenmesi ve gıda güvenliği, gelir dağılımında adaletin sağlanması, çevre ve insan sağlı̆̆1 gibi konuların giderek önem kazanması tarım sektörünün de önemini korumasına neden olmaktadır. Özellikle sanayileşme ile birlikte yaşanan kentleşme olgusu artan nüfusun doyurulmasını yani gida güvenliğini önemli bir noktaya taşımıştır. Bununla birlikte başta tarım arazisi olmak üzere tarımsal üretimde kullanılan girdilerdeki kıtlık ve iklim değişikleri, doğal kaynakları ve üretim faktörlerini arttırarak tarımsal üretimin arttırılamayacağını göstermektedir. Bu nedenle tarımsal üretimde istikrarı sağlamanın en güvenli yolu kaynakların optimal düzeyde dağıtılması ve maksimum verimin elde edilmesidir.

İktisatçılar serbest ticaretin, optimal kaynak dağılımını sağlamada etkili olacağını ileri sürmektedirler. Ricardo'nun Karşılaştırmalı üstünlükler teorisi, faktör donatımına dayanan Heckscher-Ohlin modeli serbest ticaretin uzmanlaşmaya yol açtığını ve ülkelerin refahını arttırdığını ifade eder. Dış ticaret yazınında geliştirilen diğer teorik modeller, (Filiztekin, 2006: 102-103) varsayımlar değiştirildikçe ülkelerin uzmanlaşma kalıpları ve bunların değişimleri konusunda farklı sonuçlara varıldığını göstermektedir. Bu nedenle uzmanlaşmanın var olup olmadığı yada sürekliliği ampirik bulgulara dayanan bir araştırma sorusu haline gelmektedir. Teorik modellerde uzmanlaşma kavramı belirli olmasına rağmen, verilere ulaşmada karşılaşılan güçlükler nedeniyle nasıl ölçüleceği konusunda geniş bir tartışma bulunmaktadır. Teorik temeli zayıf olmakla beraber literatürde en çok kullanılan yöntem Balassa (1965) tarafından geliştirilen Açıklanmış Karşılaştırmalı Üstünlükler (AKÜ) indeksidir (Filiztekin, 2006: 107).

$\mathrm{Bu}$ çalışmada Türkiye'deki illerin tarımsal üretimde sahip oldukları karşılaştırmalı üstünlükleri ölçülmeye çalışılmaktadır. Bu amaç doğrultusunda Uyumlaştırılmış Mal tanım ve kod sisteminin tarım sektörü ile ilgili olan ilk 24 faslına ait ihracat verileri kullanılarak Açıklanmış Karşılaştırmalı Üstünlükler indeksi hesaplanmıştır. Bilgimiz dahilinde bölgesel düzeyde yapılmış olan bu ilk çalışma ile illerin hangi tarımsal ürünlerde rekabet gücüne sahip oldukları ortaya konulacak ve tarım sektöründeki optimal kaynak dağılımı ile ilgili yararlı bilgilere ulaşılacaktır. Bu amaç doğrultusunda çalışma beş bölümden oluşacaktır. Devam eden bölümde Türkiye'de ve bölgesel düzeyde tarımsal üretim hakkında çok kısa bilgiler verildikten sonra literatürde yer alan çalışmalar sunulacaktır. Dördüncü bölümde çalışmada kullanılan veri seti ile yöntem ve beşinci bölümde ise elde edilen ampirik bulgular tartışılacaktır. Çalışma sonuç bölümü ile sona erecektir.

\section{TÜRKIYYE'DE TARIM SEKTÖRÜ}

Türkiye'nin tarımsal üretim değeri 2007-2018 dönemi arasında 850 milyon TL civarında durağan bir yapı göstermektedir. 2018 yılını hariç tutarsak, 2007-2017 döneminde bitkisel üretim değeri yıllık ortalama \%0,95 artış göstermiştir. Dönem içerisinde en yüksek değerine 2015 yılında ulaştıktan sonra 2018 yılında 1046 milyon TL'ye ulaşmıştır. 


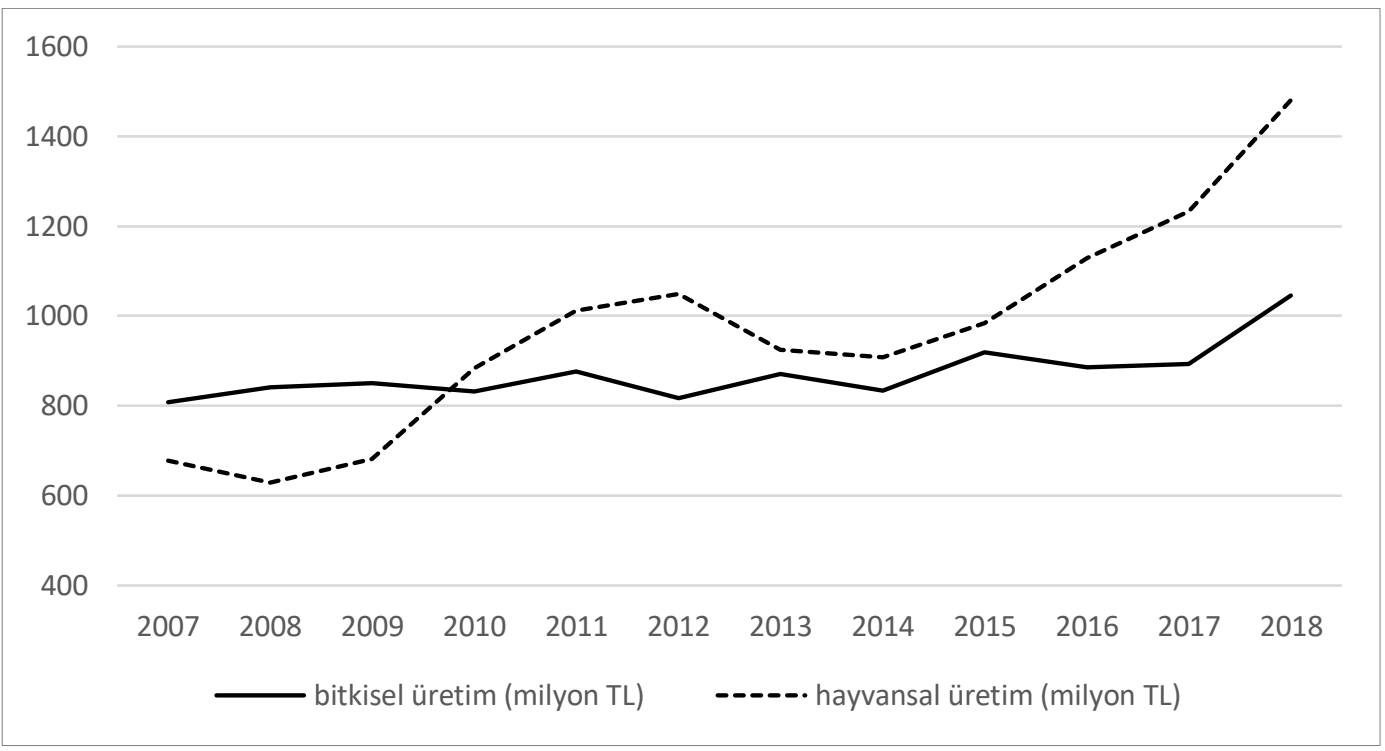

Şekil 1: Türkiye' deki bitkisel ve hayvansal üretim değerleri (Reel)

Kaynak: TÜİK, Dış Ticaret İstatistikleri, (Erişim Tarihi: 05.10.2019)

Bitkisel üretimin gösterdiği bu dalgayı seyir, tarım sektöründe geleneksel üretimin önemli bir paya sahip olduğuna işaret etmektedir. Diğer taraftan hayvansal üretim 2012 yılında yaşanan bir daralmadan sonra çok ciddi büyüme trendi göstermektedir. 2008 yılındaki 630 milyon TL ile en düşük seviyesine gerileyen hayvansal üretim değeri daha sonra yıllık ortalama $\% 7,5^{\prime}$ luk bir büyüme göstermiştir. Bu rakamlar da hayvansal üretimin daha istikrarlı bir yapıya sahip olduğuna işaret etmektedir.

Türkiye'deki tarımsal ürünlerin dış ticaretinde görülen gelişim seyri ise aşağıdaki şekil yardımıla incelenebilir

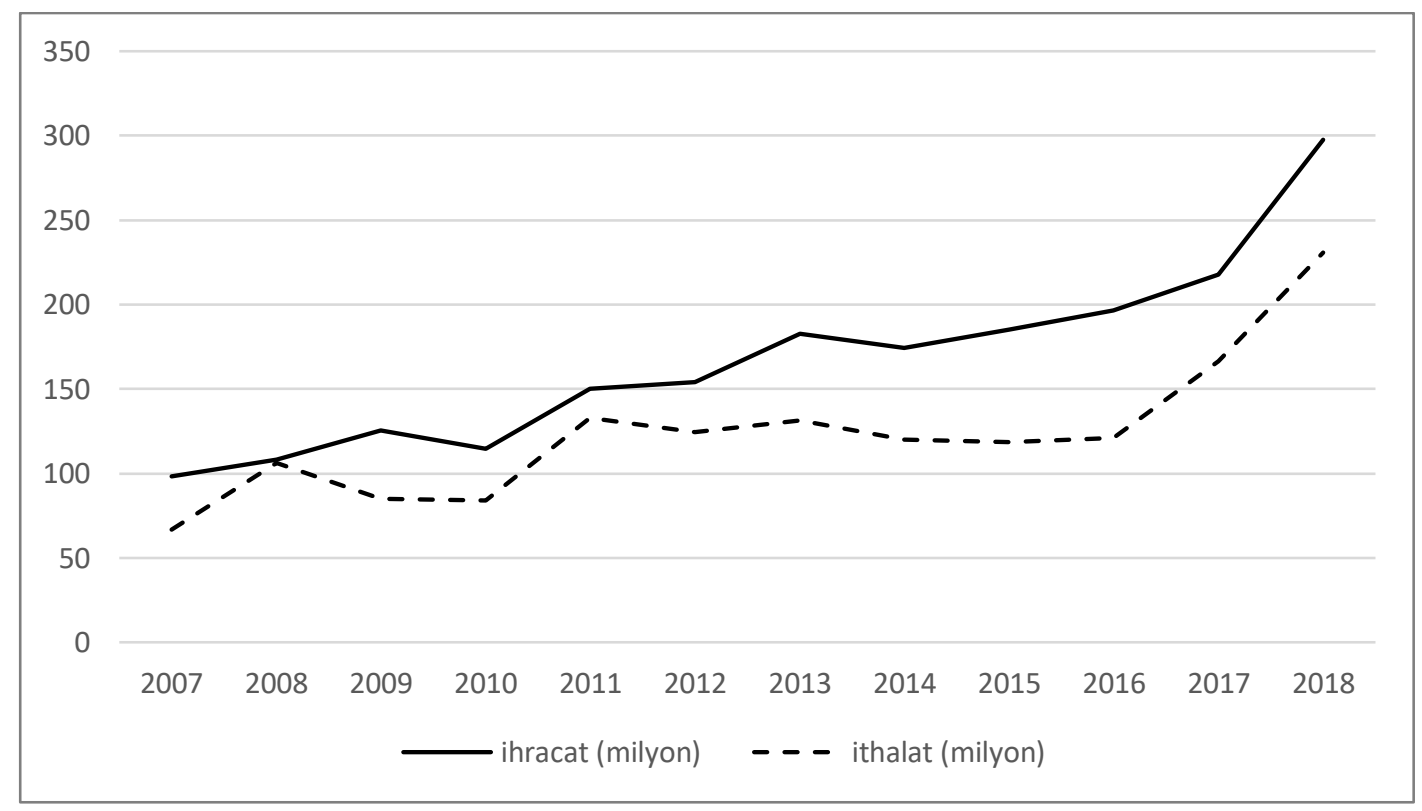

Şekil 2: Türkiye' deki tarımsal ürünlerin dış ticareti, Reel

Kaynak: TÜIK, Dış Ticaret İstatistikleri, (Erişim Tarihi: 05.10.2019) 
Şekil 2'den de görülebileceği gibi tarımsal dış ticaret istikrarlı bir şekilde artış göstermektedir. Dönem içerisinde tarımsal ihracatın ithalattan sürekli daha fazla olması tarımsal dış ticarette Türkiye'nin dış ticaret fazlası verdiğine işaret etmektedir. Bununla birlikte ihracatın yıllık ortalama \%11,3'lük bir artış göstermesinin yanında ithalatın yıllık ortalama \%15 artması tarımsal diş ticaret dengesinin bozulduğunu göstermektedir. Diğer taraftan ihracatın tarımsal üretim içerisindeki payı ortalama olarak $\% 9^{\prime}$ dur. Bu durumda Türkiye' deki tarımsal üretimin daha çok yurtiçi piyasalara yönelik yapıldığını ifade etmektedir.

İl düzeyindeki bitkisel ve hayvansal üretim değerleri için hesaplanan tanımlayıcı istatistikler ise Tablo 1'de sunulmuştur. Tabloda ilk göze çarpan unsur değişim katsayısının yüksek olmasıdır. Bu durum tarımsal üretimin her ilde farklı olmasına rağmen önemli dalgalanmalar gösterdiğine işaret etmektedir. Tabloda yer alan tanımlayıcı istatistikler 2007-2018 dönemini kapsayan ve TÜİK'den elde edilen veri seti kullanılarak tarafımızca hesaplanmıştır.

Tablo 1: İl düzeyinde bitkisel ve hayvansal üretim için tanımlayıcı istatistikler

\begin{tabular}{|c|c|c|c|c|c|c|c|c|c|c|}
\hline & \multicolumn{5}{|c|}{ bitkisel üretim } & \multicolumn{5}{|c|}{ hayvansal üretim } \\
\hline & ort. & $\begin{array}{l}\text { std. } \\
\text { sapma }\end{array}$ & $\begin{array}{l}\text { değişim } \\
\text { katsayısı }\end{array}$ & $\min$ & mak & ort. & $\begin{array}{l}\text { std. } \\
\text { sapma }\end{array}$ & $\begin{array}{l}\text { değişim } \\
\text { katsayısı }\end{array}$ & $\min$ & mak \\
\hline İstanbul & 320 & 75 & 23 & 211 & 483 & 674 & 249 & 37 & 421 & 1211 \\
\hline Tekirdağ & 1213 & 427 & 35 & 712 & 1953 & 1033 & 331 & 32 & 608 & 1742 \\
\hline Edirne & 1411 & 372 & 26 & 845 & 2176 & 999 & 308 & 31 & 588 & 1566 \\
\hline Kırklareli & 704 & 232 & 33 & 420 & 1159 & 953 & 362 & 38 & 456 & 1649 \\
\hline Balıkesir & 2061 & 461 & 22 & 1320 & 2882 & 3856 & 883 & 23 & 2726 & 5806 \\
\hline Çanakkale & 1892 & 619 & 33 & 1096 & 3326 & 1524 & 575 & 38 & 759 & 2706 \\
\hline İzmir & 3771 & 881 & 23 & 2209 & 4952 & 4172 & 1953 & 47 & 2360 & 8816 \\
\hline Aydın & 2238 & 752 & 34 & 1202 & 3650 & 1856 & 755 & 41 & 998 & 3648 \\
\hline Denizli & 1994 & 623 & 31 & 1069 & 3262 & 1587 & 757 & 48 & 675 & 3320 \\
\hline Muğla & 2112 & 543 & 26 & 1211 & 2844 & 1262 & 636 & 50 & 565 & 2908 \\
\hline Manisa & 2923 & 824 & 28 & 1902 & 4755 & 2094 & 627 & 30 & 1494 & 3432 \\
\hline Afyonkarahisar & 1457 & 443 & 30 & 883 & 2344 & 2276 & 946 & 42 & 1451 & 4507 \\
\hline Kütahya & 787 & 210 & 27 & 476 & 1138 & 1057 & 438 & 41 & 527 & 2034 \\
\hline Uşak & 673 & 252 & 37 & 268 & 1101 & 858 & 340 & 40 & 374 & 1382 \\
\hline Bursa & 3004 & 990 & 33 & 2114 & 5536 & 1490 & 571 & 38 & 956 & 2934 \\
\hline Eskişehir & 1105 & 450 & 41 & 546 & 1981 & 1027 & 403 & 39 & 563 & 1942 \\
\hline Bilecik & 484 & 106 & 22 & 309 & 681 & 280 & 71 & 25 & 216 & 475 \\
\hline Kocaeli & 389 & 84 & 22 & 251 & 511 & 729 & 163 & 22 & 566 & 1039 \\
\hline Sakarya & 1370 & 427 & 31 & 864 & 1982 & 1296 & 346 & 27 & 947 & 2079 \\
\hline Düzce & 523 & 231 & 44 & 301 & 1069 & 328 & 118 & 36 & 167 & 540 \\
\hline Bolu & 403 & 125 & 31 & 298 & 693 & 1472 & 651 & 44 & 836 & 2621 \\
\hline Yalova & 205 & 30 & 15 & 164 & 258 & 83 & 30 & 36 & 55 & 142 \\
\hline Ankara & 2655 & 795 & 30 & 1326 & 4178 & 2240 & 1361 & 61 & 1087 & 5497 \\
\hline Konya & 4939 & 2246 & 45 & 2016 & 9287 & 4787 & 2458 & 51 & 2211 & 10129 \\
\hline Karaman & 1640 & 710 & 43 & 717 & 3059 & 610 & 345 & 57 & 240 & 1349 \\
\hline Antalya & 7367 & 1970 & 27 & 4410 & 10754 & 1313 & 598 & 46 & 576 & 2647 \\
\hline Isparta & 1326 & 370 & 28 & 815 & 2187 & 799 & 366 & 46 & 336 & 1522 \\
\hline
\end{tabular}




\begin{tabular}{|c|c|c|c|c|c|c|c|c|c|c|}
\hline Burdur & 665 & 202 & 30 & 343 & 980 & 1342 & 636 & 47 & 526 & 2579 \\
\hline Adana & 3719 & 1295 & 35 & 2350 & 6755 & 1555 & 667 & 43 & 664 & 2997 \\
\hline Mersin & 5044 & 1528 & 30 & 3597 & 8449 & 1317 & 523 & 40 & 607 & 2504 \\
\hline Hatay & 2429 & 382 & 16 & 1984 & 3217 & 785 & 366 & 47 & 405 & 1559 \\
\hline Kahramanmaraş & 1531 & 423 & 28 & 935 & 2303 & 1082 & 678 & 63 & 457 & 2534 \\
\hline Osmaniye & 840 & 207 & 25 & 495 & 1234 & 495 & 186 & 38 & 247 & 899 \\
\hline Kırıkkale & 380 & 174 & 46 & 130 & 749 & 339 & 170 & 50 & 115 & 713 \\
\hline Aksaray & 1010 & 351 & 35 & 519 & 1671 & 1295 & 825 & 64 & 413 & 3167 \\
\hline Niğde & 1307 & 544 & 42 & 688 & 2399 & 1135 & 701 & 62 & 340 & 2607 \\
\hline Nevşehir & 837 & 262 & 31 & 482 & 1308 & 428 & 213 & 50 & 197 & 912 \\
\hline Kırşehir & 619 & 216 & 35 & 360 & 1065 & 769 & 617 & 80 & 270 & 2357 \\
\hline Kayseri & 1193 & 467 & 39 & 565 & 2096 & 1816 & 850 & 47 & 879 & 3614 \\
\hline Sivas & 784 & 319 & 41 & 321 & 1288 & 1980 & 938 & 47 & 747 & 3825 \\
\hline Yozgat & 1040 & 337 & 32 & 506 & 1574 & 1268 & 587 & 46 & 527 & 2503 \\
\hline Zonguldak & 303 & 103 & 34 & 178 & 488 & 431 & 137 & 32 & 222 & 733 \\
\hline Karabük & 82 & 17 & 20 & 58 & 108 & 177 & 63 & 36 & 102 & 328 \\
\hline Bartın & 198 & 56 & 28 & 107 & 259 & 283 & 66 & 23 & 201 & 449 \\
\hline Kastamonu & 507 & 101 & 20 & 373 & 658 & 1276 & 537 & 42 & 625 & 2344 \\
\hline Çankırı & 337 & 75 & 22 & 189 & 447 & 646 & 328 & 51 & 348 & 1326 \\
\hline Sinop & 310 & 102 & 33 & 148 & 463 & 435 & 153 & 35 & 221 & 714 \\
\hline Samsun & 2406 & 623 & 26 & 1416 & 3577 & 1553 & 631 & 41 & 837 & 2860 \\
\hline Tokat & 1431 & 428 & 30 & 863 & 2347 & 1180 & 601 & 51 & 516 & 2599 \\
\hline Çorum & 1046 & 348 & 33 & 518 & 1748 & 1273 & 488 & 38 & 674 & 2292 \\
\hline Amasya & 1014 & 342 & 34 & 513 & 1715 & 859 & 494 & 57 & 452 & 1997 \\
\hline Trabzon & 808 & 300 & 37 & 406 & 1366 & 680 & 232 & 34 & 416 & 1171 \\
\hline Ordu & 1306 & 788 & 60 & 632 & 3177 & 831 & 364 & 44 & 422 & 1653 \\
\hline Giresun & 766 & 456 & 59 & 320 & 1952 & 482 & 213 & 44 & 278 & 961 \\
\hline Rize & 1214 & 548 & 45 & 580 & 2441 & 167 & 78 & 47 & 91 & 377 \\
\hline Artvin & 368 & 136 & 37 & 230 & 645 & 406 & 166 & 41 & 177 & 745 \\
\hline Gümüşhane & 199 & 70 & 35 & 125 & 315 & 362 & 125 & 35 & 215 & 632 \\
\hline Erzurum & 389 & 123 & 31 & 226 & 587 & 2718 & 1457 & 54 & 1088 & 5861 \\
\hline Erzincan & 411 & 97 & 24 & 254 & 608 & 663 & 330 & 50 & 319 & 1366 \\
\hline Bayburt & 81 & 34 & 42 & 29 & 139 & 350 & 162 & 46 & 154 & 718 \\
\hline Ăğn & 196 & 45 & 23 & 121 & 276 & 1726 & 941 & 55 & 628 & 3752 \\
\hline Kars & 161 & 77 & 48 & 104 & 394 & 1916 & 1068 & 56 & 660 & 4119 \\
\hline Iğdır & 201 & 83 & 41 & 110 & 341 & 862 & 600 & 70 & 245 & 2128 \\
\hline Ardahan & 32 & 15 & 48 & 14 & 58 & 1090 & 510 & 47 & 518 & 2190 \\
\hline Malatya & 992 & 442 & 45 & 353 & 1733 & 937 & 458 & 49 & 463 & 1914 \\
\hline Elazı ̆ & 571 & 196 & 34 & 388 & 997 & 1065 & 523 & 49 & 575 & 2336 \\
\hline Bingöl & 98 & 21 & 22 & 70 & 134 & 792 & 434 & 55 & 291 & 1546 \\
\hline Tunceli & 58 & 14 & 25 & 37 & 90 & 335 & 150 & 45 & 140 & 584 \\
\hline Van & 203 & 77 & 38 & 136 & 373 & 1971 & 855 & 43 & 803 & 3747 \\
\hline Muş & 302 & 147 & 49 & 135 & 642 & 1660 & 726 & 44 & 673 & 3152 \\
\hline
\end{tabular}




\begin{tabular}{lccccc|ccccc}
\hline Bitlis & 258 & 145 & 56 & 119 & 535 & 725 & 309 & 43 & 288 & 1338 \\
\hline Hakkari & 148 & 25 & 17 & 79 & 178 & 472 & 229 & 48 & 205 & 960 \\
\hline Gaziantep & 1636 & 992 & 61 & 890 & 4369 & 1082 & 765 & 71 & 298 & 2921 \\
\hline Adıyaman & 873 & 479 & 55 & 397 & 2058 & 519 & 304 & 59 & 212 & 1171 \\
\hline Kilis & 347 & 150 & 43 & 173 & 613 & 167 & 89 & 53 & 50 & 321 \\
\hline Şanlıurfa & 3986 & 1650 & 41 & 1943 & 7964 & 1894 & 1084 & 57 & 604 & 4376 \\
\hline Diyarbakır & 1958 & 714 & 36 & 834 & 3217 & 2112 & 1462 & 69 & 823 & 5602 \\
\hline Mardin & 1296 & 494 & 38 & 555 & 1983 & 821 & 425 & 52 & 248 & 1645 \\
\hline Batman & 326 & 122 & 37 & 110 & 507 & 642 & 400 & 62 & 171 & 1592 \\
\hline Şırnak & 205 & 71 & 35 & 65 & 310 & 427 & 302 & 71 & 142 & 1173 \\
\hline Siirt & 363 & 151 & 42 & 117 & 617 & 578 & 348 & 60 & 142 & 1378 \\
\hline
\end{tabular}

En yüksek bitkisel üretim değerine sahip olan ilk beş il sırası ile Antalya, Mersin, Konya, Şanlıurfa ve İzmir'dir. Bu iller arasında ise en yüksek değişim katsayısına sahip olan bir başka deyişle üretiminde en fazla dalgalanma yaşanan iller ise Konya ve Şanlıurfa'dır. Bu sonuçlarda iklimsel avantajlara sahip olan illerin önemli üretim düzeylerine sahip olduklarına işaret etmektedir. Diğer taraftan en yüksek ortalama hayvansal üretim değerlerine sahip olan iller ise Konya, İzmir, Balıkesir, Erzurum, Afyon ve Ankara'dır. En yüksek değişim katsayısına sahip olan iller ise Konya, Erzurum ve Ankara'dır. Bu sonuçlar tarımsal üretimde genel olarak yıldan yıla büyük değişimler ortaya çıtığını göstermekte ve istikrarsızlı̆̆ın coğrafi konum ile yakından ilişkili olduğuna işaret etmektedir.

\section{LITERATÜR TARAMASI}

Bugüne kadar Türk tarımının rekabet gücünü araştırmaya yönelik birçok çalışma yapılmıştır. $\mathrm{Bu}$ çalışmalar birbirlerinden karşılaştırmaya konu edilen ülke grupları ve mal/ürün grupları bakımından farklılaşmaktadır. Bazı çalışmalar tarım sektörünün tamamını araştırma konusu yapmışken bazıları belli bir ürün grubu üzerinde yoğunlaşmışlardır.

Ülkeler arasında karşılaştırma yapan ve tarım sektörünün genelini kapsayan çalışmalardan, Karaalp (2011), 1996-2008 dönemini kapsayan çalışmasında Türkiye ile Bağımsız Devletler Topluluğu arasındaki karşılaştırmalı üstünlükleri 16 farklı mal grubunu ele alarak araştırmıştır. Çalışma sonuçları Türkiye'nin tarım sektöründe karşılaştırmalı üstünlüğe sahip olduğunu göstermektedir. Bunun yanında Türkiye ile Bağımsız Devletler Topluluğu ülkeleri arasında yoğun bir ikili ticaretin yaşandığı ve endüstri içi ticaretin de geliştiği belirtilmiştir. Erkan (2012), 2000-2008 yılları arasını kapsayan çalışmasında Türkiye ile Suriye'nin karşılaştırmalı üstünlüklerinin belirlenmesi için STIC Rev. 3 sinıflandırmasını kullanmıştır. Çalışma sonuçlarına göre 66 mal grubunun sadece 9'unda Türkiye, Suriye karşısında karşılaştırmalı dezavantaja sahiptir. Şahinli (2013), 2008 yılı için Türkiye ile AB arasındaki tarımsal rekabet gücünü hesaplamıştır. 420 tarımsal ürün için yapılan analizde Türkiye'nin 95 üründe karşılaştırmalı üstünlüğe sahip olduğu belirtilmiştir. Yalçınkaya vd. (2014), Türkiye'nin Çine karşı olan rekabet gücünü ISIC Rev. 4 kapsamından sınıflandırılan sektörleri ele alarak incelemişlerdir. 2002-2013 dönemi için hesaplanan Açıklanmış Karşılaştırmalı Üstünlükler (AKÜ) endeksi sonuçlarına göre Türkiye tarım sektöründe Çin'e karşı rekabet gücüne sahip değildir. Kalaycı (2017), serbest ticaret anlaşması imzalanan ülkelerle yapılan dış ticarette Türkiye' nin karşılaştırmalı üstünlüğünü STIC Rev. 3 sınıflandırmasını kullanarak 
2012-2016 dönemi için analiz etmiştir. Elde edilen sonuçlar Türkiye'nin canlı hayvanlar ve gıda maddeleri sektöründe karşılaştırmalı üstünlüğe sahip olduğunu göstermektedir. Bashimov (2017a), 2001-2015 dönemi için MINT ülkelerinin tarımsal hammaddeler ve gıda ürünlerindeki karşılaştırmalı üstünlüğünü araştırmıştır. Çalışma sonuçları incelenen ülke grubu içinde Endonezya ve Türkiye'nin yüksek rekabet gücüne sahip olduklarını göstermektedir. Bu sonuçlara göre Türkiye tarımsal hammaddeler ve gıda maddelerinde net ihracatçı ülke konumundadır. Güneş ve Tan (2017), Türkiye ve Rusya arasındaki ikili ticarete konu olan, tarım sektörü de dâhil 14 sektör için statik ve dinamik AKÜ endeksi hesaplamışlardır. Çalışma sonuçları Türkiye'nin Rusya karşısında statik karşılaştırmalı üstünlüğe sahip olduğunu fakat benzer sonuçların dinamik analizde ortaya çıkmadığını vurgulamaktadir.

Türkiye tarım sektörü için zaman serisi analizi yapan ve rekabetçi gücünün gelişimini inceleyen çalışmalar da literatürde önemli bir yer teşkil etmektedir. Baltacı vd. (2012), 20022009 dönemini ele alarak Türkiye'nin rekabetçi sektörlerini STIC Rev. 3 sinıflandırmasına göre belirlemeye çalışmışlardır. Çalışma sonuçlarına göre en rekabetçi sektörler arasında meyvesebzeler sektörü ile şeker, şeker ürünleri ve bal sektörü yer almaktadır. Şahinli (2014), 20002011 yılları arasında Türkiye tarım sektörünün rekabet gücünün belirlenebilmesi için 601 adet tarımsal ürün için AKÜ endeksi hesaplanmıştır. Sonuçlar Türkiye'nin 78 adet tarımsal üründe karşılaştırmalı üstünlüğe sahip olduğunu göstermektedir. Erkan vd. (2015), 1993-2012 yılları arasında Türkiye'nin dünya piyasalarında karşılaştırmalı üstünlüğünü belirlemeye çalışmışlardır. Çalışma sonuçları Türkiye'nin sebze ve alt gruplarında önemli bir karşılaştırmalı üstünlüğe sahip olduğunu göstermektedir. Bununla birlikte sahip olunan üstünlügün incelenen dönemde giderek azaldığı belirtilmektedir. Şahin (2016), Türkiye'nin tarımsal gıda ürünlerindeki rekabet gücünü 2000-2014 döneminde STIC Rev. 3 sınıflandırmasını kullanarak analiz etmiştir. Çalışma sonuçları tarımsal gıda ürünlerinde rekabet gücünün düşük olduğunu göstermektedir. Sarıçoban ve Kösekahyaoğlu (2017), STIC Rev. 3 sinıflandırmasını kullandıkları çalışmalarında 1996-2015 dönemi için Türkiye'nin tarımsal ürün gruplarındaki rekabet gücünü incelemişlerdir. Analiz sonuçlarına göre Türkiye'nin 66 tarımsal ürün grubundan 24'ünde rekabet avantajına sahip olduğu 42 ürün grubunda ise rekabet dezavantajına sahip olduğu görülmektedir. Ayrıca Türkiye'nin rekabet avantajına sahip olduğu ürün gruplarının sadece 7 'sinde güçlü üstün konumda olduğu tespit edilmiştir. Özgün ve Uzunöz (2017), 2001-2015 döneminde Türkiye gıda ürünleri sektörünün nasıl bir gelişim gösterdiğini araştırmışlardır. Çalışma sonuçları Türkiye'nin gıda ürünleri sektöründe rekabetçi bir yapıya sahip olmadığını göstermektedir. Bashimov (2017b), 20022015 yıllarını kapsayan çalışmasında Harmonize Sistem sınıflandırmasını kullanarak Türkiye tarım sektörünün karşılaştırmalı üstünlügünü analiz etmiştir. AKÜ indeksi sonuçlarına göre Türkiye 11 ürün grubunda karşılaştırmalı üstünlüğe ve 13 ürün grubunda karşılaştırmalı dezavantaja sahiptir. Bashimov (2018), 2001-2015 dönemini kapsayan çalışmasında Türkiye'de canlı hayvanlar ve hayvansal ürünlerin diş ticaret yapısı ve rekabetçilik düzeyini analiz etmiştir. Araştırma bulguları söz konusu ürün gruplarında rekabet gücünün oldukça düşük olduğunu göstermektedir. Keskingöz (2018), 2001-2017 dönemi için Harmonize Sistem sınıflandırmasını kullanarak Türk tarım sektörünün 24 fasıla göre rekabetçi gücünü analiz etmiştir. Çalışma sonuçlarına göre Türkiye, 24 fasıldan 12'sinde karşılaştırmalı üstünlüğe, 11 'inde ise rekabet gücüne sahiptir. 
Rekabet gücü analizlerini spesifik bir veya birkaç ürün grubu için yapan çalışmalardan bazıları ise şu şekildedir. Serin ve Civan (2008), 1995-2005 döneminde Türkiye'nin AB piyasasında domates, zeytinyağı ve meyve suyu sektörlerinde rekabetçi üstünlüğe sahip olup olmadığını araştırmışlardır. Ulaştıkları sonuç, Türkiye'nin meyve suyu ve zeytinyağında güçlü karşılaştırmalı üstünlüğe sahip olduğunu fakat domates piyasasında bu sonucun geçerli olmadığını göstermektedir. Fidan (2009), Türkiye'nin AB ülkeleri karşısındaki 1990-2003 dönemi için narenciyedeki rekabetçiliğini ölçtüğü çalışmasında AKÜ ve RTA endekslerini hesaplamıştır. Elde edilen sonuçlar Türkiye'nin özellikle limon ve greyfurtta önemli rekabetçi güce sahip olduğunu göstermektedir. Çoban vd. (2010), Türk tarım sektörünün AB ülkeleri karşısındaki rekabet gücünü 1996-2007 dönemi için incelemişlerdir. Analiz sonuçları Türkiye'nin meyve-sebze, şeker-bal ve şeker hammaddesi ürün gruplarında yüksek rekabet gücüne canlı hayvan ürün grubunda ise oldukça düşük rekabet gücüne sahip olduğunu göstermektedir. Şahinli (2012), Türkiye ve AB üyesi ülkelerde canlı hayvancılık sektörünün rekabet gücünü araştırmıştır. Çalışma sonuçları Türkiye'nin canlı hayvancılık sektöründe AB üyesi ülkelere ait piyasalarda karşılaştırmalı üstünlük ve rekabet gücüne sahip olmadığına işaret etmektedir. Peker (2015), 1994-2011 dönemi için hububat-baklagil alt sektörünün AB pazarı karşısında rekabet gücü araştırılmıştır. Belli ürünlerde yüksek rekabet gücüne sahip olunsa bile bu durumun oldukça dalgalı bir seyir izlediği ve rekabet gücünün zaman içerisinde giderek azaldığg belirtilmiştir. Kuşat (2019), su ürünleri sektöründe Türkiye'nin uluslararası rekabet gücünü 2013-2017 dönemini ele alarak incelemiştir. Sonuçlar en yüksek rekabet gücüne sahip ülkenin Hindistan olduğunu göstermektedir. Hindistan ve Vietnam'dan sonra Türkiye'nin de rekabet gücü oldukça yüksek bulunmuştur. Terin ve Yavuz (2019), Türkiye'nin kanatlı eti ticaretindeki rekabetçi gücünü belli başlı ihracatçı ülkeler ile karşılaştırarak analiz etmişlerdir. 2001-2017 dönemi için yapılan analiz sonuçları Türkiye'nin orta düzey rekabet gücüne sahip olduğunu fakat var olan rekabet gücünün dönem içerisinde giderek arttığını göstermektedir.

Yukarıda kısa bir özeti verilmeye çalışılan oldukça geniş literatürde, Türkiye için yapılmış olan bölgesel bir analize rastlanılmamıştır. Bu çalışma literatürdeki bu boşluğu giderebilmek amacı ile konuya mikro düzlemde yaklaşmakta ve illerin tarımsal ihracat performansları incelenmeye çalışılmaktadır.

\section{YÖNTEM ve VERİ SETİ}

Ekonomik teoriye göre iki bölge ya da ülke arasındaki karşılaştırmalı üstünlüğü hesaplayabilmek için ilgili ülkeler arasında ticaretin olmadığı durumdaki ilgili mallar ile ilgili göreli fiyatların kullanılması gerekmektedir. Bununla birlikte göreli fiyatlara ilişkin veri setine ulaşmanın neredeyse imkânsız olması teoriye dayalı hesaplamanın mümkün olmadığını göstermektedir. Bu nedenle bir ülke veya bölgenin karşılaştırmalı üstünlügünü dolaylı olarak ölçülmesine imkân tanıyan bir proxy modelin belirlenmesi zorunluluğu doğmuştur. Göreli fiyatları hesaplamak için gerekli verilerin yokluğunda (girdi fiyatları gibi) Balassa, karşılaştırmalı üstünlüğü hesaplamak için yaygın olarak kullanılan bir yöntem geliştirmiştir (Beyene, 2017: 56-57). İlk önce Liesner (1958) tarafından ortaya atılan daha sonra Balassa (1965) tarafından geliştirilen Açıklanmış Karşılaştırmalı Üstünlükler (AKÜ) kavramı için devam 
edilen yıllarda birçok farklı alternatifler geliştirilmiştirb. Bu çalışmada kullanılan Balassa'nın geliştirmiş olduğu AKÜ endeksi, bir ülke veya bölgenin belirli bir ürün açısından gerçekleştirdiği nispi ihracat payının analize konu olan tüm ülkeler ve tüm ürünler açısından gerçekleştirdiği nispi ihracat payına oranını ifade etmektedir (Saraçoğlu, 2015:4). Ülkelerin mevcut ihracat verilerinden yararlanılarak oluşturulan bu indeks, karşılaştırmalı üstünlügüun nedenine inmeden görünen bir avantaj farkının olup olmadığını açıklamaya çalışmaktadır (Erkan, 2012:198). AKÜ endeksi şu şekilde formüle edilebilir.

$$
A K \ddot{U}_{i j}=\frac{X_{i j} / X_{i}}{X_{w j} / X_{w}}
$$

(1) nolu denklemdeki $A K \mathrm{Ü}_{i j}$, i bölgesinin j ürünündeki açıklanmış karşılaştırmalı üstünlükler endeksini, $X_{i j}$, i bölgesinin j malı ihracatını, $X_{i}$, i bölgesinin toplam ihracatını, $X_{w j}$, j ürününün toplam dünya ihracatını ve $X_{w}$, toplam dünya ihracatını göstermektedir (Balassa ve Nolan, 1989:9). Endeks değeri 0 ile $\infty$ arasında değer almaktadır. Endeks değerinin 1'den büyük olması ilgili ülkenin ilgili üründe karşılaştırmalı üstünlüğe sahip olduğunu, 1'den küçük olması ise karşılaştırmalı dezavantaja sahip olduğunu göstermektedir. Hinloopen ve Marrewijk (2001), ampirik uygulamada daha sağlıklı çıarsamalarda bulunmak ve tutarlı yorumlar yapabilmek için endeksin 1'den büyük olması durumunda ilave sınıflandırmalar yapmışlardır. Buna göre,

$$
\begin{array}{ll}
0<A K \ddot{U}_{i j}<1 & ; \text { karşılaştırmalı üstünlük yoktur. } \\
1<A K \ddot{U}_{i j} \leq 2 & ; \text { zayıf karşılaştırmalı üstünlük vardır } \\
2<A K \ddot{U}_{i j} \leq 4 & ; \text { orta karşılaştırmalı üstünlük vardır } \\
4<A K \ddot{U}_{i j} & \text {; güçlü karşılaştırmalı üstünlük vardır }
\end{array}
$$

(1) nolu denklem ile ifade edilen AKÜ endeksi ile ilgili açılanması gereken bir diğer önemli nokta "dünya" ile ne kastedildiğidir. Bu ifadedeki anlam araştırma örneklemine göre değişkenlik göstermektedir ve en geniş anlamıyla dünyanın ihracatını gösterebileceği gibi bir grup ülkenin hatta tek bir ülkenin ihracatını da gösterebilir (Erlat ve Erlat, 2012: 12). Bu çalışmada Türkiye'deki illerin tarımsal ürünlerdeki karşılaştırmalı üstünlükleri araştırıldığı için (1) nolu denklemdeki "dünya” ihracatı Türkiye'nin toplam ihracatını göstermektedir.

Bu çalışmada Türkiye'deki illerin tarımsal ürün ticaretindeki performansları 2015 ve 2018 yılları ihracat verileri kullanılarak incelenmeye çalışılmıştır. 2018 yılı illere ait tarımsal ihracat verilerinin elde edilebildiği son yıl olduğu için seçilmiştir. Diğer yandan karşılaştırma olanağ elde edebilmek için 2015 yılı kullanılmıştır. Karşılaştırmada benzer ekonomik koşulların, daha tutarlı sonuçlar elde edilmesinde yardımcı olacağı düşünüldügüünden birbirine yakın iki yıl çalışmaya dâhil edilmiştir. Bu amaç doğrultusunda Uyumlaştırılmış (Harmonize) Mal Tanım ve Kod Sisteminin (HS) 2 haneli ihracat verileri kullanılmıştır. 2 haneli Harmonize mal tanım sinıflandırmasının ilk 24 fasılı tarımsal ürün ve grupları ifade etmektedir ve bu sınıflandırma aşağıdaki Tablo 2'de yer almaktadır. Çalışmada kullanılan bütün ihracat verileri Türkiye İstatistik Kurumunun Dış Ticaret İstatistikleri veri tabanından elde edilmiştir.

\footnotetext{
b Ayrıntılı açıklama için Vollrath (1991) ve Saraçoğlu (2015)’na bakılabilir.
} 
Tablo 2: HS sınıflandırmasındaki tarımsal ürünlere ait kategoriler

\begin{tabular}{|c|c|}
\hline 1 & Canli hayvanlar \\
\hline 2 & Etler ve yenilen sakatat \\
\hline 3 & $\begin{array}{l}\text { Balıklar, kabuklu hayvanlar, yumuşakçalar ve suda yaşayan diğer omurgasız } \\
\text { hayvanlar }\end{array}$ \\
\hline 4 & Süt ürünleri, yumurtalar, tabii bal, diğer yenilebilir hayvansal menşeli ürünler \\
\hline 5 & $\begin{array}{l}\text { Diğer hayvansal menşeli ürünler (kıl, kemik, boynuz, fildişi, mercan, bağırsak, } \\
\text { vb.) }\end{array}$ \\
\hline 6 & $\begin{array}{l}\text { Canlı ağaçlar ve diğer bitkiler, yumrular, kökler ve benzerleri, kesme çiçekler ve } \\
\text { süs yaprakları }\end{array}$ \\
\hline 7 & Yenilen sebzeler ve bazı kök ve yumrular \\
\hline 8 & Yenilen meyveler ve sert kabuklu meyveler \\
\hline 9 & Kahve, çay, paraguay çayı ve baharat \\
\hline 10 & Hububat \\
\hline 11 & Değirmencilik ürünleri, malt, nişasta, inülin, buğday gluteni \\
\hline 12 & $\begin{array}{l}\text { Yağlı tohum ve meyveler, muhtelif tane, tohum ve meyveler, sanayiide ve tıpta } \\
\text { kullanılan bitkiler, saman ve kaba yem }\end{array}$ \\
\hline 13 & Lak, sakız, reçine ve diğer bitkisel özsu ve hülasalar \\
\hline 14 & $\begin{array}{l}\text { Örülmeye elverişli bitkisel maddeler, tarifenin başka yerinde belirtilmeyen veya } \\
\text { yer almayan bitkisel ürünler }\end{array}$ \\
\hline 15 & $\begin{array}{l}\text { Hayvansal ve bitkisel katı ve sıvı yağlar, yemeklik katı yağlar, hayvansal ve } \\
\text { bitkisel mumlar }\end{array}$ \\
\hline 16 & $\begin{array}{l}\text { Et, balık, kabuklu hayvanlar, yumuşakçalar veya diğer su omurgasızlarının } \\
\text { müstahzarları }\end{array}$ \\
\hline 17 & Şeker ve şeker mamulleri \\
\hline 18 & Kakao ve kakao müstahzarları \\
\hline 19 & Hububat, un, nişasta veya süt müstahzarları, pastacılık ürünleri \\
\hline 20 & $\begin{array}{l}\text { Sebzeler, meyveler, sert kabuklu meyveler ve bitkilerin diğer kısımlarından elde } \\
\text { edilen müstahzarlar }\end{array}$ \\
\hline 21 & $\begin{array}{l}\text { Yenilen çeşitli gıda müstahzarları (kahve hülasaları, çay hülasaları, mayalar, } \\
\text { soslar, diyet mamaları, vb.) }\end{array}$ \\
\hline 22 & Meşrubat, alkollü içkiler ve sirke \\
\hline 23 & Gıda sanayiinin kalıntı ve döküntüleri, hayvanlar için hazırlanmış kaba yemler \\
\hline 24 & Tütün ve tütün yerine geçen işlenmiş maddeler \\
\hline
\end{tabular}

Kaynak: TÜİK, Dış Ticaret İstatistikleri Veri Tabanı

\section{AMPIRİK SONUÇLAR}

Türkiye'deki illerin tarımsal rekabet gücünü ölçebilmek için Açıklanmış Karşılaştırmalı Üstünlükler indeksi 2015 ve 2018 yılları için hesaplanmış ve elde edilen sonuçlar aşağıdaki tablolarda sunulmuştur. Aşağıdaki Tablo 3'de AKÜ indeks sonuçları tarımsal ürün ve gruplara göre elde edilen sonuçları göstermektedir. 
Tablo 3: HS sınıflandırmasına göre AKÜ indeks sonuçları: il sayıları

\begin{tabular}{|c|c|c|c|c|c|c|c|c|}
\hline \multirow[b]{2}{*}{$\begin{array}{c}\text { HS } \\
\text { Sinifi }\end{array}$} & \multicolumn{4}{|c|}{2015} & \multicolumn{4}{|c|}{2018} \\
\hline & $0<\mathrm{AK} \ddot{U}<1$ & $1<\mathrm{AKÜ}<2$ & $2<\mathrm{AK} \ddot{\mathrm{U}}<4$ & 4<AKÜ & $0<\mathrm{AK} \ddot{\mathrm{U}}<1$ & $1<\mathrm{AKÜ}<2$ & $2<\mathrm{AKÜ}<4$ & 4<AKÜ \\
\hline 1 & 73 & 1 & 3 & 4 & 71 & 1 & 2 & 7 \\
\hline 2 & 61 & 4 & 6 & 10 & 66 & 3 & 5 & 7 \\
\hline 3 & 68 & 2 & 5 & 6 & 69 & 1 & 4 & 7 \\
\hline 4 & 57 & 7 & 6 & 11 & 59 & 4 & 7 & 11 \\
\hline 5 & 70 & 1 & 5 & 5 & 70 & 3 & 3 & 5 \\
\hline 6 & 69 & 2 & 1 & 9 & 66 & 3 & 6 & 6 \\
\hline 7 & 60 & 10 & 4 & 7 & 57 & 10 & 9 & 5 \\
\hline 8 & 60 & 11 & 10 & 0 & 59 & 11 & 10 & 1 \\
\hline 9 & 72 & 2 & 1 & 6 & 71 & 3 & 3 & 4 \\
\hline 10 & 69 & 4 & 4 & 4 & 67 & 4 & 3 & 7 \\
\hline 11 & 56 & 6 & 5 & 14 & 58 & 5 & 5 & 13 \\
\hline 12 & 61 & 7 & 5 & 8 & 65 & 4 & 6 & 6 \\
\hline 13 & 78 & 1 & 0 & 2 & 79 & 0 & 0 & 2 \\
\hline 14 & 71 & 1 & 2 & 7 & 73 & 2 & 1 & 5 \\
\hline 15 & 74 & 4 & 0 & 3 & 74 & 4 & 3 & 0 \\
\hline 16 & 67 & 6 & 3 & 5 & 72 & 3 & 3 & 3 \\
\hline 17 & 65 & 5 & 7 & 4 & 68 & 1 & 8 & 4 \\
\hline 18 & 69 & 4 & 5 & 3 & 70 & 6 & 1 & 4 \\
\hline 19 & 58 & 8 & 8 & 7 & 59 & 10 & 4 & 8 \\
\hline 20 & 62 & 7 & 8 & 4 & 58 & 10 & 5 & 8 \\
\hline 21 & 67 & 7 & 4 & 3 & 71 & 5 & 4 & 1 \\
\hline 22 & 67 & 3 & 5 & 6 & 60 & 9 & 3 & 9 \\
\hline 23 & 64 & 8 & 5 & 4 & 67 & 5 & 3 & 6 \\
\hline 24 & 79 & 1 & 0 & 1 & 79 & 1 & 0 & 1 \\
\hline
\end{tabular}

Tablo 3'e göre HS 11 (değirmencilik ürünleri ...) ürün grubunda 2015 yılında 25 il ve 2018 yılında 23 il karşılaştırmalı üstünlüğe sahiptir. Bu iller arasında 2015 yılında 14 il ve 2018 yılında 13 il güçlü bir karşılaştırmalı üstünlüğe sahiptir. HS 04 (süt ürünleri, yumurtalar, ...) ürün grubu da benzer performansa sahiptir. Bu ürün grubunda 11 il güçlü bir karşılaştırmalı üstünlüğe sahip iken 2018 yılında 7, 2015 yılında ise 6 il orta karşılaştırmalı üstünlüğe sahiptir. Bunların yanında HS 19 (hububat, un, ...), HS 7 (yenilen sebzeler ...) ve HS 2 (etler ve yenilen sakatat) ürün grupları da dikkat çekici performansa sahiptir. HS 8 (yenilen meyveler ...) ürün grubunda 2015 yılında 21 il ve 2018 yılında 22 il karşılaştırmalı üstünlüğe sahip olmasına rağmen sadece 1 ilin 2018 yılında güçlü bir karşılaştırmalı üstünlüğe sahip olduğu görülmektedir.

Diğer taraftan en düşük performansların görüldüğü ürün grupları olarak HS 24 (tütün ...) ve HS 13 (Lak, sakız, ...) ön plana çıkmaktadır. Bu iki ürün grubunu HS 01 (canlı hayvanlar) , HS 14 (örülmeye elverişli bitkisel maddeler ...) ve HS 15 (hayvansal ve bitkisel yağlar ...) takip etmektedir. Bu belirtilen gruplarda üretimin çok az sayıda illerde toplandığı anlaşılmaktadır. Örneğin HS 24 ürün grubunda sadece iki ilin karşılaştırmalı üstünlüğü vardır bunlardan birinin AKÜ indeks değeri 4'den büyüktür. Dikkat çekici diğer bir husus ise iki yıl arasında önemli değişikliklerin ortaya çıkmasıdır. Örneğin HS 15 ürün grubunda 2015 yılında 3 tane il güçlü karşılaştırmalı üstünlüğe sahip iken bu durumlarını 2018 yılında koruyamamışlardır. Tablo 3, bu kriter göz önüne alınarak incelendiğinde benzer durumun hemen her ürün 
grubunda yaşandığı görülmektedir. Bu durum ise tarımsal üretimin dönemsel ya da mevsimsel etkilerden arındırılamadığının bir işareti olarak yorumlanabilir.

Aşağıdaki Tablo 4 ise il düzeyinde hesaplanan AKÜ indeks değerlerini göstermektedir.

Tablo 4: İllere göre AKÜ indeks sonuçları: HS ürün grup sayısı

\begin{tabular}{|c|c|c|c|c|c|c|c|c|c|}
\hline & & \multicolumn{4}{|c|}{2015} & \multicolumn{4}{|c|}{2018} \\
\hline & & $0<\mathrm{AKÜ}<1$ & $1<\mathrm{AK} \ddot{\mathrm{U}}<2$ & $2<\mathrm{AK} \ddot{U}<4$ & 4<AKÜ & $0<\mathrm{AKÜ}<1$ & $1<\mathrm{AKÜ}<2$ & $2<\mathrm{AKÜ}<4$ & 4<AKÜ \\
\hline 1 & Adana & 14 & 3 & 3 & 4 & 15 & 0 & 3 & 6 \\
\hline 2 & Adiyaman & 22 & 0 & 0 & 2 & 22 & 0 & 1 & 1 \\
\hline 3 & Afyon & 19 & 1 & 2 & 2 & 21 & 0 & 1 & 2 \\
\hline 4 & Ağr1 & 18 & 2 & 3 & 1 & 17 & 3 & 2 & 2 \\
\hline 5 & Amasya & 22 & 0 & 1 & 1 & 21 & 0 & 1 & 2 \\
\hline 6 & Ankara & 12 & 7 & 5 & 0 & 13 & 8 & 1 & 2 \\
\hline 7 & Antalya & 19 & 2 & 1 & 2 & 20 & 1 & 1 & 2 \\
\hline 8 & Artvin & 19 & 1 & 1 & 3 & 20 & 1 & 2 & 1 \\
\hline 9 & Aydın & 22 & 1 & 1 & 0 & 22 & 1 & 1 & 0 \\
\hline 10 & Balıkesir & 16 & 2 & 4 & 2 & 16 & 0 & 6 & 2 \\
\hline 11 & Bilecik & 22 & 0 & 0 & 2 & 22 & 0 & 1 & 1 \\
\hline 12 & Bingöl & 23 & 0 & 0 & 1 & 21 & 1 & 1 & 1 \\
\hline 13 & Bitlis & 23 & 0 & 0 & 1 & 22 & 0 & 2 & 0 \\
\hline 14 & Bolu & 21 & 2 & 0 & 1 & 19 & 2 & 0 & 3 \\
\hline 15 & Burdur & 19 & 0 & 0 & 5 & 20 & 2 & 0 & 2 \\
\hline 16 & Bursa & 17 & 1 & 1 & 5 & 16 & 1 & 4 & 3 \\
\hline 17 & Çanakkale & 20 & 1 & 1 & 2 & 20 & 1 & 2 & 1 \\
\hline 18 & Çankırı & 21 & 0 & 2 & 1 & 22 & 0 & 1 & 1 \\
\hline 19 & Çorum & 18 & 1 & 3 & 2 & 17 & 2 & 4 & 1 \\
\hline 20 & Denizli & 15 & 2 & 1 & 6 & 18 & 2 & 1 & 3 \\
\hline 21 & Diyarbakır & 19 & 2 & 1 & 2 & 20 & 0 & 2 & 2 \\
\hline 22 & Edirne & 18 & 4 & 1 & 1 & 18 & 2 & 3 & 1 \\
\hline 23 & Elazığ & 21 & 1 & 1 & 1 & 23 & 0 & 0 & 1 \\
\hline 24 & Erzincan & 22 & 0 & 1 & 1 & 23 & 0 & 0 & 1 \\
\hline 25 & Erzurum & 23 & 0 & 0 & 1 & 21 & 2 & 0 & 1 \\
\hline 26 & Eskişehir & 20 & 0 & 2 & 2 & 19 & 3 & 0 & 2 \\
\hline 27 & Gaziantep & 16 & 6 & 1 & 1 & 17 & 4 & 3 & 0 \\
\hline 28 & Giresun & 21 & 1 & 1 & 1 & 21 & 1 & 0 & 2 \\
\hline 29 & Gümüşhane & 22 & 0 & 2 & 0 & 23 & 0 & 0 & 1 \\
\hline 30 & Hakkari & 23 & 0 & 0 & 1 & 18 & 3 & 1 & 2 \\
\hline 31 & Hatay & 19 & 2 & 3 & 0 & 21 & 1 & 2 & 0 \\
\hline 32 & Isparta & 20 & 1 & 2 & 1 & 18 & 3 & 2 & 1 \\
\hline 33 & Mersin & 15 & 5 & 3 & 1 & 17 & 4 & 0 & 3 \\
\hline 34 & İstanbul & 17 & 2 & 5 & 0 & 16 & 3 & 5 & 0 \\
\hline 35 & İzmir & 19 & 1 & 2 & 2 & 18 & 3 & 2 & 1 \\
\hline 36 & Kars & 24 & 0 & 0 & 0 & 23 & 0 & 0 & 1 \\
\hline 37 & Kastamonu & 22 & 0 & 0 & 2 & 21 & 1 & 1 & 1 \\
\hline 38 & Kayseri & 16 & 3 & 3 & 2 & 18 & 3 & 2 & 1 \\
\hline 39 & Kırklareli & 22 & 0 & 0 & 2 & 21 & 1 & 0 & 2 \\
\hline 40 & Kırşehir & 18 & 3 & 1 & 2 & 20 & 1 & 0 & 3 \\
\hline 41 & Kocaeli & 19 & 2 & 0 & 3 & 18 & 1 & 3 & 2 \\
\hline 42 & Konya & 16 & 2 & 3 & 3 & 17 & 1 & 3 & 3 \\
\hline 43 & Kütahya & 23 & 0 & 0 & 1 & 22 & 1 & 0 & 1 \\
\hline 44 & Malatya & 20 & 2 & 1 & 1 & 20 & 0 & 2 & 2 \\
\hline 45 & Manisa & 18 & 4 & 2 & 0 & 19 & 4 & 1 & 0 \\
\hline
\end{tabular}




\begin{tabular}{l|l|llll|llll}
\hline $\mathbf{4 6}$ & Kahramanmaras & 19 & 2 & 0 & 3 & 16 & 2 & 4 & 2 \\
\hline $\mathbf{4 7}$ & Mardin & 20 & 1 & 0 & 3 & 21 & 0 & 1 & 2 \\
\hline $\mathbf{4 8}$ & Muğla & 21 & 1 & 1 & 1 & 22 & 1 & 0 & 1 \\
\hline $\mathbf{4 9}$ & Muş & 23 & 0 & 0 & 1 & 23 & 0 & 0 & 1 \\
\hline $\mathbf{5 0}$ & Nevşehir & 20 & 2 & 1 & 1 & 19 & 3 & 0 & 2 \\
\hline $\mathbf{5 1}$ & Niğde & 20 & 2 & 2 & 0 & 20 & 1 & 2 & 1 \\
\hline $\mathbf{5 2}$ & Ordu & 22 & 1 & 0 & 1 & 22 & 1 & 0 & 1 \\
\hline $\mathbf{5 3}$ & Rize & 19 & 2 & 2 & 1 & 16 & 6 & 0 & 2 \\
\hline $\mathbf{5 4}$ & Sakarya & 17 & 0 & 4 & 3 & 18 & 2 & 2 & 2 \\
\hline $\mathbf{5 5}$ & Samsun & 19 & 1 & 1 & 3 & 20 & 1 & 0 & 3 \\
\hline $\mathbf{5 6}$ & Siirt & 21 & 0 & 1 & 2 & 22 & 0 & 1 & 1 \\
\hline $\mathbf{5 7}$ & Sinop & 21 & 1 & 0 & 2 & 20 & 2 & 1 & 1 \\
\hline $\mathbf{5 8}$ & Sivas & 20 & 2 & 1 & 1 & 21 & 1 & 1 & 1 \\
\hline $\mathbf{5 9}$ & Tekirdă & 21 & 1 & 0 & 2 & 21 & 0 & 1 & 2 \\
\hline $\mathbf{6 0}$ & Tokat & 21 & 0 & 2 & 1 & 21 & 0 & 1 & 2 \\
\hline $\mathbf{6 1}$ & Trabzon & 21 & 1 & 2 & 0 & 22 & 0 & 2 & 0 \\
\hline $\mathbf{6 2}$ & Tunceli & 20 & 2 & 0 & 2 & 21 & 1 & 0 & 2 \\
\hline $\mathbf{6 3}$ & Şanlıurfa & 20 & 3 & 0 & 1 & 17 & 2 & 3 & 2 \\
\hline $\mathbf{6 4}$ & Uşak & 19 & 0 & 1 & 4 & 20 & 0 & 1 & 3 \\
\hline $\mathbf{6 5}$ & Van & 18 & 5 & 1 & 0 & 21 & 0 & 1 & 2 \\
\hline $\mathbf{6 6}$ & Yozgat & 20 & 2 & 1 & 1 & 21 & 0 & 2 & 1 \\
\hline $\mathbf{6 7}$ & Zonguldak & 21 & 0 & 1 & 2 & 21 & 1 & 0 & 2 \\
\hline $\mathbf{6 8}$ & Aksaray & 21 & 0 & 0 & 3 & 21 & 1 & 0 & 2 \\
\hline $\mathbf{6 9}$ & Bayburt & 22 & 0 & 0 & 2 & 24 & 0 & 0 & 0 \\
\hline $\mathbf{7 0}$ & Karaman & 22 & 0 & 1 & 1 & 22 & 0 & 0 & 2 \\
\hline $\mathbf{7 1}$ & Kırıkkale & 22 & 0 & 0 & 2 & 20 & 2 & 0 & 2 \\
\hline $\mathbf{7 2}$ & Batman & 19 & 2 & 2 & 1 & 20 & 0 & 2 & 2 \\
\hline $\mathbf{7 3}$ & Şırnak & 17 & 5 & 1 & 1 & 17 & 4 & 2 & 1 \\
\hline $\mathbf{7 4}$ & Bartın & 21 & 1 & 1 & 1 & 23 & 0 & 0 & 1 \\
\hline $\mathbf{7 5}$ & Ardahan & 24 & 0 & 0 & 0 & 24 & 0 & 0 & 0 \\
\hline $\mathbf{7 6}$ & Iğdır & 17 & 2 & 3 & 2 & 22 & 1 & 0 & 1 \\
\hline $\mathbf{7 7}$ & Yalova & 19 & 0 & 0 & 5 & 19 & 0 & 1 & 4 \\
\hline $\mathbf{7 8}$ & Karabük & 18 & 0 & 4 & 2 & 21 & 0 & 0 & 3 \\
\hline $\mathbf{7 9}$ & Kilis & 18 & 2 & 2 & 2 & 15 & 3 & 2 & 4 \\
\hline $\mathbf{8 0}$ & Osmaniye & 21 & 1 & 2 & 0 & 20 & 2 & 0 & 2 \\
\hline $\mathbf{8 1}$ & Düzce & 18 & 3 & 1 & 2 & 19 & 4 & 1 & 0 \\
\hline & & & & & & & & & \\
\hline
\end{tabular}

Yukarıdaki tablo incelendiğinde ilk dikkat çekici olan nokta birçok ilin sadece bir ya da iki ürün grubunda karşılaştırmalı üstünlüğe sahip olduklarıdır. Bu noktada en dikkat çekici olan iller ise Ardahan, Bayburt, Karaman, Muş, Kütahya, Kars, Kastamonu, Kırklareli, Gümüşhane, Elazığ, Erzincan, Erzurum, Bingöl, Adıyaman ve Bitlis'tir. Ardahan hem 2015 hem de 2018 yıllarında hiçbir ürün grubunda karşılaştırmalı üstünlüğe sahip değildir. Bayburt, 2015 yılında HS 07 (yenilen sebzeler ...) ve HS 09 (kahve, çay, ...) ürün gruplarında karşılaştırmalı üstünlüğe sahip iken 2018 yılında hiçbir ürün grubunda üstünlüğü yoktur. Muş, 2015 yılında sadece HS 12 (yağlı tohum ve meyveler ...) ve 2018 yılında HS 08 (yenilen meyveler ...) ürün gruplarında güçlü karşılaştırmalı üstünlüğe sahiptir. Kars 2015 yılında hiçbir ürün grubunda üstünlüğe sahip değil iken 2018 yılında HS 23'de (gıda sanayinin kalıntı ve döküntüleri ...) karşılaştırmalı üstünlüğe sahiptir. 2018 yılında Gümüşhane ve Erzincan sadece HS 20 (sebzeler, meyveler ...) ve Elazı $\breve{g}$ sadece HS 02 (etler ve yenilen sakatat) ürün grubunda karşılaştırmalı üstünlüğe sahiplerdir. 
En iyi performansa sahip olan iller ise Ankara, Adana, Burdur, Bursa, Denizli, Gaziantep, Mersin ve Konya'dır. Ankara 12 ürün grubunda karşılaştırmalı üstünlüğe sahip iken 2018 yılında sadece ikisinde güçlü karşılaştırmalı üstünlüğe sahiptir. Burdur, 2015 yılında beş farklı ürün grubunda güçlü karşılaştırmalı üstünlüğe sahip iken bu rakam 2018 yılında ikiye gerilemiştir. 2015 yılında Adana dört, Bursa beş ve Denizli altı ürün grubunda güçlü karşılaştırmalı üstünlüğe sahip iken 2018 yılında Adana altı, Bursa ve Denizli üç ürün grubunda güçlü üstünlüğe sahiptir. Bu bağlamda iki yıl arasında performansını geliştiren tek ilin Adana olduğu görülmektedir.

2015 ve 2018 yıllarında HS 01 (canlı hayvanlar)' de en yüksek AKÜ indeks değerine sahip olan il Kilis'tir. HS 02' de 2015 yılında Bolu, 2018 yılında ise Elazı ğ en yüksek AKÜ değerine sahiptir. HS 03'de (balıklar, kabuklu hayvanlar ...) her iki yılda da Muğla, HS 04'de (süt ürünleri, yumurtalar) Kütahya, HS 05'de (diğer hayvansal ürünler ...) Zonguldak, HS 07' de (yenilen sebzeler ...) Kastamonu, HS 09'da (kahve, çay, ...) Bartın, HS 10'da (hububat) Adıyaman, HS 13' de (Lak, sakız, ...) Mersin, HS 16'da (et, balık, ...) Çanakkale ve HS 24'de (tütün ...) İzmir en yüksek indeks değerlerine sahiptirler. 2015 ve 2018 yıllarında sirasıyla HS 06' da (canlı ağaçlar ve diğer bitkiler ...) Yalova ve Karabük, HS 08'de (yenilen meyveler ...) Malatya ve Muş, HS 11'de (değirmencilik ürünleri ...) Erzurum ve Bilecik, HS 12' de (yağlı tohum ve meyveler ...) Muş ve Osmaniye, HS 14' de (örülmeye elverişli bitkisel maddeler ...) Diyarbakır ve Adana, HS 15'de (hayvansal ve bitkisel yağlar ...) Şanlıurfa ve Diyarbakır, HS 17' de (şeker ve şeker mamulleri) Hakkâri ve Amasya, HS 18' de (kakao ...) Sakarya ve Hakkâri, HS 19'da (hububat, un, ...) Karaman ve Çankırı, HS 20'de (sebzeler, meyveler, ...) Erzincan ve Gümüşhane, HS 21'de (yenilen çeşitli gıda müstahzarları) Bitlis ve Tekirdağ, HS 22'de (meşrubat, ...) Siirt ve Tunceli, HS 23'de (gıda sanayinin kalıntı ve döküntüleri, ...) Kırıkkale ve Kars en yüksek AKÜ değerlerine sahip olan illerdir.

\section{SONUÇ}

$\mathrm{Bu}$ çalışmada, Balassa tarafından geliştirilen AKÜ indeksi yardımıyla Türkiye'deki illerin tarımsal üretimdeki karşılaştırmalı üstünlükleri hesaplanmıştır. 2015 ve 2018 yılları için yapılan hesaplamada HS mal tanım ve sinıflandırma sisteminde yer alan tarımsal ürün gruplarına ait ihracat verileri kullanılmıştır.

Keskingöz (2018) ve Bashimov (2017b)'ye göre Türkiye'nin karşılaştırmalı üstünlüğe sahip olduğu ürün grupları HS 07, HS 08, HS 11, HS 14, HS 17, HS 19, HS 20, HS21 ve HS 24'dür. Bunun yanında net ithalatçı pozisyonunda olduğu ve karşılaştırmalı dezavantaja sahip olunan ürün grupları ise HS 01, HS 10, HS 12, HS 13, HS 15 ve HS 23'dür. Söz konusu iki çalışma bulgularına göre Türkiye'nin 24 ürün grubunun yaklaşık olarak yarısında karşılaştırmalı üstünlüğe sahip olduğu söylenebilmektedir. Bu çalışmada hesaplanan illere ait AKÜ indeks sonuçları da literatürde yer alan diğer çalışma sonuçlarını destekler niteliktedir. Türkiye'nin karşılaştırmalı üstünlüğe sahip olduğu ürün gruplarında görece daha fazla ilin rekabet gücü yüksek bulunmuştur. Örneğin HS 07 ürün grubunda 23 ilin ve HS 08' de 22 ilin karşılaştırmalı üstünlüğe sahip olduğu görülmektedir. Benzer şekilde HS 11'de 24 il, HS 19'da 23 il ve HS 20 'de 21 il karşılaştırmalı üstünlüğe sahiptir. Bunun yanında HS 14, HS 17 ve HS 21'de daha az ilin (ortalama olarak 10-12) karşılaştırmalı üstünlüğe sahip olduğu görülmektedir. Fakat en ilginç sonuç HS 24' de ortaya çımaktadır. Bu ürün grubunda sadece iki ilin (İstanbul ve İzmir) karşılaştırmalı üstünlüğe sahip olduğu görülmektedir. Bu illerden İzmir güçlü karşılaştırmalı 
üstünlüğe sahip iken, İstanbul zayıf karşılaştırmalı üstünlüğe sahiptir. Diğer taraftan Türkiye'nin net ithalatçı olduğu ürün grupları içerisinde HS 01'de 10 ilin, HS 10'da 14 ilin, HS 12'de 20 ilin, HS 23'de 17 ilin ve HS 15'de 7 ilin Türkiye'nin ihracat performansı içerisinde karşılaştırmalı üstünlüğe sahip olduğu görülmektedir. Diğer taraftan Türkiye'nin karşılaştırmalı üstünlüğe sahip olmadığı HS 04 ürün grubunda 19 ilin yüksek AKÜ indeks değerlerine sahip olduğu görülmektedir. Bu illerden 11'nin ise AKÜ indeks skoru 4'den büyüktür yani güçlü karşılaştırmalı üstünlüğe sahiplerdir. Bu durum ciddi ve istikrarlı bir tarımsal politika uygulanmadığ taktirde bu illerin tarımsal gelirlerinde gelecek dönemlerde önemli sıkıntıların yaşanabileceğine işaret etmektedir.

Elde edilen bu sonuçlar Türkiye' de herhangi bir ilin sahip olduğu tarımsal yapısı veya üretimi ile ön plana çıkmadığını ifade etmektedir. Birçok il sınırlı sayıda tarımsal ürün grubunda karşılaştırmalı üstünlüğe sahiptir. Ayrıca illerin hesaplanan AKÜ indeks değerlerinde iki yıl arasında görülen ciddi farklılaşma tarımsal üretimin geleneksel bir yapıya sahip olduğuna işaret etmektedir. Türkiye'nin dünya piyasasında rekabet gücüne sahip olduğu ürün gruplarında, ülke sınırları içerisinde birçok ilin karşılaştırmalı üstünlüğe sahip olması herhangi bir ilin ihracat performansı ile ön plana çıkmadığını göstermektedir. Bunun yanında dünya piyasasında dezavantaja sahip olunan ürün gruplarında dahi birçok ilin ülke sınırları içerisinde rekabetçi pozisyonda olmaları kaynakların optimal kullanılamadığına işaret etmektedir. Söz konusu illerin tarımsal üretimleri, ülkenin rekabet üstünlüğüne sahip olmamasından dolayı zaman içerisinde olumsuz yönde etkilenecek ve kaynak dağılımı üzerinde negatif etkiler ortaya çıkaracaktır.

Tartışılan bütün konular Türkiye'deki tarımsal üretimin çok küçük bir oranının piyasaya yönelik yapıldığını göstermektedir. Bu durumu ortadan kaldırabilmek için illere en yüksek karşılaştırmalı üstünlüğe sahip oldukları ürün gruplarına göre teşvikler verilmelidir. Böyle bir politika tercihi biryandan büyük ölçekli tarımsal işletmelerin kurulmasına ve dış piyasaya yönelik üretimin yapılmasına yardımcı olacak diğer yandan tarımsal üretimin ve gelirin daha istikrarlı bir yapıya kavuşmasına yol açacaktır.

\section{KAYNAKÇA}

Balassa, B. (1965). Trade Liberalisation and "Revealed" Comparative Advantage. The Manchester School, 33(2), 99-123

Balassa, B. ve Noland, M. (1989). “Revealed” Comparative Advantage in Japan and the United States. Journal of International Economic, 4(2), 8-22.

Baltacı, A., Burgazoğlu, H. ve Kılıç, S. (2012). Türkiye'nin Rekabetçi Sektörleri ve Trakya Bölgesinin Payı. Çankır Karatekin üniversitesi İktisadi ve İdari Bilimler Fakültesi Dergisi, 2(1), 1-19

Bashimov, G. (2017a). MINT Ülkelerinde İhracatın Açıklanmış Karşılaştırmalı Üstünlükler Perspektifinden Analizi: Tarım ve Gıda Ürünleri Örneği. İktisadi ve İdari Bilimler Dergisi, $3(6), 235-253$

Bashimov, G. (2017b). Türkiye'nin Tarım ve Gıda Ürünlerinde Karşılaştırmalı Üstünlüğü. Türk Tarım ve Doğa Bilimleri Dergisi, 4(3), 319-330 
Bashimov, G. (2018). Türkiye' de Canlı Hayvanlar ve Hayvansal Ürünlerin Dış Ticaret Yapısının Analizi. Uludağ Üniversitesi Ziraat Fakültesi Dergisi, 32(1), 1-13

Beyene, H.G. (2017). Trade Integration and Revealed Comparative Advantages of Sub-Saharan Africa and Middle East and North Africa Merchandize Export. Journal of Economic Cooperation and Development, 38(1), 55-96

Çoban, O., Peker, A.E. ve Kubar, Y. (2010). Türk Tarımının Avrupa Birliği Ülkeleri Karşısındaki Sektörel Rekabet Gücü. SÜ İ̈BF Sosyal ve Ekonomik Araştırmalar Dergisi, 10(20), 247-266

Erkan, B. (2012). Ülkelerin Karşılaştırmalı İhracat Performanslarının Açıklanmış Karşılaştırmalı Üstünlük Katsayılarıyla Belirlenmesi: Türkiye-Suriye Örneği. ZKÜ Sosyal Bilimler Dergisi, 8(15), 195-218

Erkan, B., Arpacı, B.B., Yaralı, F. ve Güvenç, İ. (2015). Türkiye'nin Sebze İhracatında Karşılaştırmalı Üstünlükler. KSÜ Doğa Bilimleri Dergisi, 18(4), 70-76

Erlat, G. ve Erlat, H. (2012). Türkiye'nin Ortadoğu Ülkeleri ile Olan Ticareti, 1990-2002. Tartışma Metni 2012/26, TEK, 1-17

Fidan, H. (2009). Comparison of Citrus Sector Competitiveness between Turkey and EU-15 Member Countries. HortScience, 44(1), 89-93

Filiztekin, A. (2006). Türkiye' de Açıklanmış Karşılaştırmalı Üstünlüklerin Evrimi. Uluslararası Ekonomi ve Dış Ticaret Politikası, 1(1), 101-116.

Güneş, S. ve Tan, M. (2017). Static and Dynamic Revealed Comparative Advantage: A Comparative Analysis of Turkey and Russia. İktisadi Yenilik Dergisi, 4(3), 22-38

Hinloopen, J. ve Marrewijk, C.V. (2001). On the Empirical Distribution of the Balassa index. Review of World Economics, 137(1), 1-35

Kalaycı, C. (2017). Serbest Ticaret Anlaşmalarının Türkiye'nin Dış Ticaretine Etkisi: Açıklanmış Karşılaştırmalı Üstünlükler Endeksi Uygulaması. Uluslararası Ekonomi ve Yenilik Dergisi, 3(2), 133-147

Karaalp, H.S. (2011). Competitiveness of Turkey in Eurasia: A Comparison with CIS Countries. China-USA Business Review, 10(9), 727-744

Keskingöz, H. (2018). Türkiye'nin Tarım Sektörünün Karşılaştırmalı Üstünlükler Yöntemiyle Analizi. BMIJ, 6(2), 508-523

Kuşat, N. (2019). Su Ürünleri Sektörü Rekabet Gücü Analizi: Türkiye ve Beş Lider Ülke Örneği. Acta Aquatica Turcica, 15(1), 43-54

Liesner, H.H. (1958). The European Common Market and British Industry. The Economic Journal, 68(270), 302-316

Özgün, F. ve Uzunöz, M. (2017). Evaluation of Global Competitiveness Power of Food Sector in Turkey: An Analysis of Revealed Comparative Advantages (RCA). International Journal of Humanities and Social Science Invention, 6(4), 2319-7717 
Peker, A.E. (2015). Türkiye Hububat ve Baklagil Alt Sektörünün Avrupa Birliği Pazarı Karşısındaki Rekabet Gücü. Kahramanmaraş Sütçü İmam Üniversitesi İktisadi ve İdari Bilimler Fakültesi Dergisi, 5(2), 1-20

Saraçoğlu, S. (2015). Türkiye Tarım Ürünlerinin Avrupa Birliği Ülkelerinin Tarım Ürünleri Karşısındaki Uluslararası Rekabet Gücü. EY International Congress on Economics II "Growth, Inequality and Poverty", November, Ankara.Turkey.

Sarıçoban, K. ve Kösekahyaoğlu, L. (2017). Türkiye'nin Tarımsal Ürünlerdeki İhracat Rekabet Gücünün Ölçülmesi: 1996-2015 Dönemi Üzerine Bir Analiz. ASSAM Uluslararası Hakemli Dergi, 4(7), 78-96

Serin, V. ve Civan, A. (2008). Revealed Comparative Advantage and Competitiveness: A Case Study for Turkey towards the EU. Journal of Economic and Social Research, 10(2), 25-41

Şahin, D. (2016). Tarımsal Gıda Ürünlerinde Karşılaştırmalı Üstünlügüun Ölçümü: Türkiye Örneği. Uluslararası Sosyal Araştırmalar Dergisi, 9(43), 2177-2184

Şahinli, M.A. (2012). Rekabet Gücü: Türkiye ve Avrupa Birliği Üyesi Ülkelerde Canlı Hayvancllık Sektörünün Durumu. Yüzüncü Yıl Üniversitesi Tarım Bilimleri Dergisi, 22(2), 91-98

Şahinli, M.A. (2013). Comparative Advantage of Agriculture Sector between Turkey and European Union. African Journal of Agricultural Research, 8(10), 884-895

Şahinli, M.A. (2014). Revealed Comparative Advantage and Competitiveness: Turkey Agriculture Sector. Yüzüncü Yıl Üniversitesi Tarmm Bilimleri Dergisi, 24(3), 210-217

Terin, M. ve Yavuz, F. (2019). Türkiye Kanatlı Eti Sektörünün Uluslararası Rekabetçiliğinin Seçilmiş Ülkelerle Karşılaştırmalı Analizi. KSÜ Tarım ve Doğa Dergisi, 22(Ek Sayı:1), 188194

TÜİK, Dış Ticaret İstatistikleri Veri Tabanı, http://www.tuik.gov.tr/PreTablo.do?alt_id=1046 (Erişim 05.10.2019)

Vollrath, T.L. (1991). A Theoretical Evaluation of Alternative Trade Intensity Measures of Revealed Comparative Advantage. Weltwirtschaftliches Archiv, 127, 265-280

Yalçınkaya, H., Çılbant, Ç., Erataş, F. ve Hartoğlu, D. (2014). Açıklanmış Karşılaştırmalı Üstünlükler Ekseninde Rekabet Gücünün Analizi: Türk-Çin Dış Ticareti Üzerine Bir Uygulama. Yönetim ve Ekonomi Araştırmaları Dergisi, 24, 41-57 